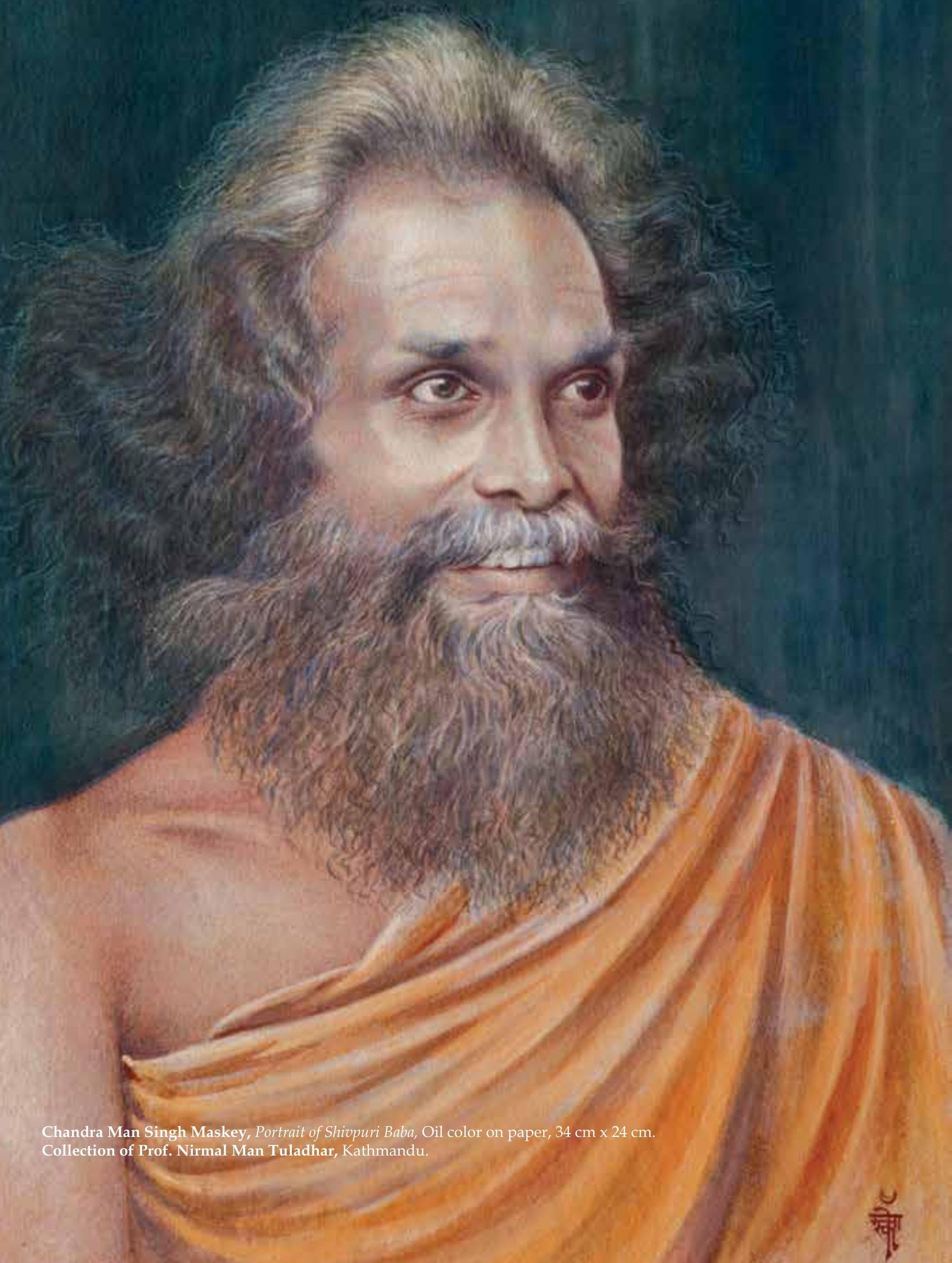




\title{
WIDENING SPHERE OF MODERN ART AND LITERATURE IN NEPAL: A STUDY OF THE INTERFACE BETWEEN THEM
}

\author{
Prof. Abhi Subedi, PhD
}

\begin{abstract}
I see modernism in painting in this region as an evolutionary process that should trigger discussions about its constituent features. This argument harps on the two questions. Is modernism only an emulation of the Western style and methods in paintings and literature, or is it also the evolution of native cultural consciousness that is reflected in the experiments made by painters in art and by writers in creative literary works? To answer these questions, this article includes discussions about evolutions of modernism in paintings and culture in meta-artistic and literary discourses. Examples are drawn from very selective discussions about literature and works of art for reason of space. The basic argument of this article is that modernism in Nepali paintings should be seen in its evolutionary process. Modernism in art is not a condition that we see in palpable form today. It has grown over a long period of creative engagements and efforts both by painters and literary writers. Nepali art students' exposure to art education in Kolkata and literary writers' engagements with print-capitalism in Banaras over a century ago have played significant roles in introducing modernism in both paintings and literature. But I have said clearly that the use of the Western techniques and education has played great role in this process. We can see that in the interface between art and literature, which should be seen in the widening sphere of such sharing in terms of both techniques, and native orientations.
\end{abstract}

Keywords: interface, Orientalist debate, modernism, native response, writers and painters, tesro aayaam

\section{Prologue}

This is the second part of my article entitled "Nepali paintings and poetry: reviews and reflections" published in Sirjanā (2017). In this part I want to focus on the interface of modern art and literature as creative components of culture in broader terms. The foundation of this feature of culture is exposure, education and pragmatism. I have called that an evolutionary process of modernist consciousness in Nepal that can be seen in the widening sphere of visual and creative forms of art. This evolution of modernism in art includes paintings and literature. 
I have examined modernism in art and literature as an evolutionary and tangible reality. Both concepts that constitute the methodology have great importance in the cultural studies not least in South Asia and Nepal. In addition to that I have chosen the heuristic method to show how modernism is not guided by patriotic fervour; it is a realist approach that includes historical and methodological examples of the processes of adjustment that the artists and writers have developed over a century. For that purpose the concepts discussed from both the Western and South Asian perspectives including Nepali discussions about modernism made over this period have been used as the guiding principles.

After a long association with both art and literature, I have come to realise that without examining the interface between the two it is not quite possible to examine modernism both as a philosophy and creative act in visual forms and language. Though there are no fixed dates to say when modernism in art as such began, we can use some landmarks available to understand that. I have alluded to some important discussions in this region for that.

My theory is that modernism in art in this region should be traced through certain conspicuous changes in the practice of paintings not least in the context of the twin influences of the Western styles and art education and that of the native tradition. The high critical canons will speak only partially about the spirit and history of modernism in this region. Following modernism in art in this region, therefore, is the study of the evolution of new modes and methods of paintings, sculptures and architecture.

\section{Evolution and evaluation: the Orientalist debate}

We should turn to the debate between the Orientalist school of art and its critics that became dominant in Calcutta towards the end of the $19^{\text {th }}$-century, and the beginning of the $20^{\text {th }}$-century. That debate is important for a number of reasons. First, for the first time a debate started between the native cultural tradition in art and those who introduced themes that did not appear to respect that tradition. Second, this debate shows how without naming the word it had laid the foundation not only of style but also of the modern treatment of their oeuvre by the artists. This debate was squarely related to the subject of art pedagogy that involved the apprenticeship about the Western techniques in art taught by the teachers who were familiar with the new ways of using them. It was a clash between what we see and how we see things. John Berger captures the mantra of this form of art that includes the subject in the object that one sees, in these words, "We are always looking at the relation between things and ourselves. Our vision is continually active, continually moving, continually holding things in a circle around itself, constituting what is present to us as we are". (Berger, 9). Berger evokes the spirit of the Western art as one of seeing by involving oneself in it. He repeats, "History always constitutes the relation between a present and its past. Consequently fear of the present leads to the mystification of the past. The past is not for living in; it is a well of conclusions from which we draw in order to act". (11). But the Orientalists E. B. Havell and Abanindranath Tagore towards the end 
of the $19^{\text {th }}$-century and the beginning of the $20^{\text {th }}$-century in India, in Calcutta, to be precise, had some different opinions about art. They believed that the past is not only a 'well of conclusions' but also a body of work that could be used 'for living in'.

Speaking to an interviewer the Indian painter Abraham Husain known as MF Husain, says by taking a sweep of the Western painting, "The main difference between Indian art and Western art is that in the West, after the Renaissance, they had the impressionists, then Cubism and so on. We however, had already passed those stages." He sees them in Indian 'folk art and tribal art' and claims, "We had all these elements, and we have them even today." (Husain 58). He evokes the image of Nataraja to say how 'we' had gone beyond that in our sculptures and paintings'. He sees in them how 'we' had already addressed the concerns of the West about 'depicting space and matter'. But this is the assertion of an artist, not the history of art. This is a modernist interpretation of the Orientalist argument by a painter who uses the universally applied techniques that definitely evince trainings in Western art.

But the above statement of a major artist expresses more the conviction of an artist than the history of how modernism as a form, and perception evolved in this part of the world. That involved a debate about the native tradition called Orientalism supported and promoted by E. B. Havell and Abanindranath Tagore that I will discuss in the following paragraphs.

The debate commonly ignored by art historians and critics of modern art in this region finds ample treatment in the writings of a very well-known art scholar Tapati Guha-Thakurta. In a book entitled "The Making of Indian Art" (1992) that covers discussions about artists, aesthetics and nationalism in Bengal, c. 1850-1920. Thakurta has examined the big debate that happened about the dual themes of westernisation of the art movements and practices in Calcutta. That coincided with the commercialisation and professionalization of Indian art. But this process clashed squarely with the Swadeshi movement led and promoted by the teachers and artists E. B. Havell and the well-known painter and thinker of the Tagore house Abanindranath Tagore. The orientalists also called nationalist artists stressed on the use of the native themes. But one consistent and persistent challenge to that came from artists who wanted to break away from that tradition and paint or make experimentations in the way deemed necessary for creative expression. The critiques involved eminent characters. No other than Sister Nivedita said, "An Indian painting, if it is to be really Indian and really great must appeal to the Indian heart in an Indian way...." (Cited Thakurta 187). The semantics of Indian heart being touched by art made in Indian way had some very fluid interpretations. The Orientalists, however, did work with the same spirit.

One prominent painter named Ravi Varma was the target, pioneer and a path breaker who was, in the words of Thakurta again, the target of the purists. She says, "What surfaces is primarily a Victorian puritanism, which shunned the 'vulgar' sensuality of Ravi Varma's imagery,' phasised 'reticence' and 'moral dignity' as the true stuff of art, and upheld these attributes". (187). 
This discussion was extended to include Bombay School of Art, which was called the 'bastion of mediocre Academicianism and rigid Western standards of teaching'. (188). This tirade came surprisingly from no other than the famous art critic Coomaraswamy. The 'Swodeshi ideology' became a great subject of art discussions during that period. Whatever may be the content, this argument marked a turning point in the aesthetic perception and the nature of the motif of art, especially painting in this region.

My understanding of this discussion is that the artists and art critics including the big names of the Tagore household Jarasanko were working with a great sense of ambivalence which was the early sign of modernism in paintings in this region. The ambivalence specially lay in the fact that nativists also used the western techniques of art, especially the expressive us of colours, brush techniques, as well as playing with the figurality and defining the field of action on a canvas. That ambivalence between native motifs and western techniques remains the ambivalence of modernist art in this region even to this day. Even MF Hussain who evoked the native motifs and techniques as he claimed to be entirely of this region as cited above, utilised ambivalence as power, which has always been the favourite forte of the Western artists. Anyone who loves Hussain's paintings, like me, for example, can see how that works.

Thakurta cites the points of this debate as carried in articles published in a monthly magazine called Sahitya or 'literature', which shows how the interface between art and literature in Calcutta worked during that time, also foregrounded by the involvolvent of the Tagores in this process. The emphasis on the 'specific science of painting' written in Sahitya according Thakurta, "militated against the dominant constructs of the Orientalist nationalist discourse: against the notion of the primacy of the idea and notion in painting, or the idea of the exclusive 'Indian-ness' of Indian art." (215). Besides Sahitya, another magazine entitled Shilpa o Sahitya, also laid stress on the 'importance of academic training'. Importance of Naturalism and the superiority of Western art also came up in the debate. Thakurta cites this remark of a writer named U. Ray, "My nationality consists of a legitimate and affectionate pride in all that is noble in our national life and tradition, combined with sincere regret for our shortcomings and eagerness to remove them. It is this nationality that prompts me to advocate the study of European art as a means of improving the Art of my country." (216-217). Sensuality in Ravi Varma was a subject of debate. But strong articles were written in defence of Ravi Varma. Nivedita who 'squirmed at the sight of Shakuntala lying on her stomach and of Arjun and Subhadra wooing each other in public" (212) received good reply from these writers. Ravi Varma's sensuality and theatricality received support from these reviewers.

The interface had begun through the culture of change. It would be wrong to say that it was an offshoot of the artistic pedagogy and experimentation in paintings. The literary culture had its impact in the discourse. We should take for example "the spontaneous creative atmosphere of the Jorasanko household in which he (Abanindranath Tagore) grew up" (Thakurta 228). That was the house of Rabindranath Tagore, which is 
a great museum now. We move to the realm of a creative culture that involves literature when we talk about the new movements in art in South Asia.

The above discussions made during that period mark a turning point. The debate between the two schools remained a persistent feature in the paintings and the aesthetic perception that held great significance in the study of the early phase of modern art in this region. My thesis is that to study modernism in Nepal and India these early debates hold great significance. Much has been written on this subject. But the views I am alluding to is that any discussions about modernism in our region should not ignore the debate about the moral, nativist and open expressive use of paintings. Interestingly, this debate holds equal importance in literary discussions of that period and after. This movement and debate was very significant for the study of modern art including Nepali to which I return in the following section.

\section{Genesis of modernism}

There are various interpretations about the beginning of modern art in Europe. The very interpretation of the historicity of modern art in the West also appears to have been made variously. Richard R. Brettell in his book of Oxford series entitled Modern Art 1851-1929 (1999) considers 1851 as the important year that marks the beginning of modernism in Europe especially in Britain. He considers the "the Great Exhibition of 1851, the first of a series of truly international exhibition" organised at Crystal Palace near London - that of course was an 'international exhibitions of manufactured goods from different countries' as the beginning of modernism in art. How he considers this exhibition a beginning of modernism in art becomes clear from starting the book about Modern Art with this story, and the following lines that he writes. He says, "There are troubling problems with 1851 as a starting-point, not the least of which is the fact that many of the keynote characteristics of modernism as defined in this book existed before 1851". Alluding to the two great English painters John Constable (1776-1837) and J. M. W. Turner (1775-1851) he says they died before the Crystal Palace exhibition. He considers this exhibition therefore as a landmark of the modern paintings. He also refers to poet Charles Baudelaire's review of Salon calling artists to 'be of their time' and 'to be involved in an interaction with the present'. (Brettell, 6). He mentions different dates of significance for modern art movement after 1851. Brettell introduces artistic movements from Realism to Surrealism and examines contexts of urban capitalism, the art of seeing, sexuality and body, iconography and landscape painting. These movements influenced discussions and the nature of modernism especially in the West and later in other parts of the world.

But what I would like to recall here are two different references. When this so-called first modern exhibition of art that included crafts as well, the big debate about orientalism and free creation was going on in Calcutta as discussed above. But for Nepali paintings we do not have any such discussions that would be relevant here. But interestingly, Nepali prime minister Jangabahadur Rana was travelling to Britain at the invitation of the British government from 
1850. In his team was a painter named Bhajuman Chitrakar who is said to have been influenced by some features of art in Britain especially in the expressionist dimension of colour in painting. Though he did not bring about a big revolution in Nepali paintings, his art of portraiture and the use of techniques and colour marked a change in the methods used by the traditional Nepali painters, especially in the portraits. But the true change came from the second decade of the $20^{\text {th }}$ century.

\section{Two Nepali students}

Here it is important to note that Nepali exposure to the Western and Orientalist experimentation of paintings appears to have started at this point when a few Nepali students, as introduced earlier, got exposure to the art pedagogy at Government School of Art in Calcutta. But that exposure though it happened on a small scale was a significant moment of modern art history in Nepal. To repeat what I have written earlier, "The trainings of two painters Chandraman Singh Maskey (1900-1984) and Tej Bahadur Chitrakar (1898-1971) in Calcutta in the second decade of the $20^{\text {th }}$-century, to my mind, is the first ever exposure of Nepali artists to the Western techniques, modes and methods of art education. The portraits executed by these two painters clearly show how they shifted the focus of portraiture from the traditional delineation to the expressive modes of paintings." (Subedi, Ambivalence). Their role in bringing about the transition in Nepali art begins from this apprenticeship. Madan Chitrakar sees the role of Tej Bahadur Chitrakar as one of such transition. (Chitrakar, 2004). I have written elsewhere about Chandraman
Singh Maskey's narrative about his studies at Government School of Art in conversations with me. A collector, art researcher and critic named David K Barker has prepared a remarkable unpublished book that he had sent to me in response to my article about the interest of the foreign scholars in Nepali arts, (and now available online) in which he includes Maskey's paintings, sketches, drawings and portraitures photographed by Pema T. Domingo-Barker. David Barkar makes the following observations about Maskey's art:

Maskey belongs to the eldest generation of contemporary Nepalese painters. His artistic career started in the 1920s. This was the time when Nepalese artists began to assimilate Western European ideas, which eventually stimulated the development of national secular painting and the appearance of new subjects and genres. Chandra M. S. Maskey's paintings portray scenes of everyday life, local customs and traditional holidays. The principal characters in the painting Wedding Ceremony-the bride and the wedding-guests who came to greet her-are placed in the foreground. The artist gives great attention to the postures, gestures and costumes of his characters, to various attributes of the scene and to the architectural background of the picture: the brick wall, the carved wooden shutters and plat bands of the windows and the painting of the portal all are rendered with a great precision of detail. (Barker).

Barker's observations are accurate and insightful. He describes Maskey as an 
artist who had a deep sense of culture and vision. His drawings, portraits, the paintings of the twilight zones that come from his apprenticeship in the Bengal movement about orientalism and the free and even sensuous paintings, which I believe, mark a shift in Nepali paintings all contribute to the process of shift in Nepali art. His contemporary Tej Bahadur Chitrakar's shift had a double bind, first he came from a well-known household carrying the background of the Chitrakars or artists, and second, he employs the techniques and forms of the Western art. Tej Bahadur Chitrakar's self-portrait is a remarkable work, which is used for a 'first day cover': a Nepali postage stamp. Tej Bahadur Chitrakar became a teacher of art at Durbar High School and later became head of Juddha Art School. That the major Nepali painters from the early times became teachers of art should be regarded as a great feature of early modernism in Nepali paintings. I have alluded to this later.

Chandraman Singh Maskey's art similarly, made inroads into the world of politics, ceremony and history. He was even jailed by the Rana oligarchic administration for his political inclination. While in jail Maskey made paintings for an epic entitled Sugat Saurav written by his other inmate Newar poet Chittadhar Hridaya. The images based on the Buddha's life remarkably remind us of what I call the paintings of the twilight zones mentioned in the cultural debate as described by Tapati Guha-Thakurta in Calcutta alias Kolkata.

The example of these two artists who were sent to study paintings or art to Calcutta at the Government College in the same year 1918 has been overlooked by art critics in their discussions about modernism in Nepali paintings. That is the reason why I have introduced them in the discussions about modern art in order to understand the genesis of Nepali modernism in paintings as in literature by tracing down the history of exposure to the art education and literature through print capitalism and experiment with ideas and techniques at various times. While these painters were getting education of the modern order, Nepali literary writers were engaged in expanding the sphere of literature by writing and printing books from Banaras. That was a great opening made through a process, which is called print capitalism. Much has been written about this subject of opening and shift through the use of print culture in literature. Rhoderick Chalmers' dissertation and his other articles describe this opening. (Chalmers, 2004). That the openings in both art and literature came around the same time-literature had started nearly three decades earlier and was going strong when these painters received training in Bengal-marks an important period of exposure and quest.

\section{Western modernism and native response}

One other landmark is that modernism as a concept was pronounced by the famous English novelist Virginia Woolf (1882-1941) after seeing the art exhibition organised by English painter and critic, and a member of the Bloomsbury Group Roger Fry, entitled 'Manet and the Post-Impressionists' in London in these words, 'On or about December 1910, human character changed'. (Woolf, 2010). That exhibition introduced the works of painters like Seurat, Van Gogh, Gauguin 
and Cézanne. None of them were alive then. That exhibition had caused quite a stir then, which is what modernist paintings have done in many places. But that exhibition and the announcement of that as modern by a great modern novelist Woolf should be remembered whenever we talk about the interface between art and literature. Artists and writers not only share but also create a culture, called modernism, which is a subject of discussion here. Such interface changes with time and place.

Geeta Kapur in an article written in the context of the 'exile of Maqbool Fida Husain', for example, sees the modernist myths cross the thresholds and assume new avatars and meaning with each such movement. She says:

On an opposite plane, how are modernist myths tested once they cross the threshold and encounter cultural modalities of modern as it is actually practised around the world? Contrary to the claims of the canon, modernism is countered/ complemented by distinctly different genealogies of the modern, and it flowers and shrinks at different political and cultural sites during the twentieth century. In its many avatars, modernism comes to be inscribed within different civilizational structures, national cultures and artisanal protocols whereby other linguistic and iconographic resources open up, posing questions to the western rubric of authorship and style. (Kapur 15).

Kapur posits that the canon of modernism as it is used widely faces challenges from different genealogies of the modern. She does not see a constant face of modernism; it has flowered and shrunk under various political and cultural conditions in the last century. Modernism should not be seen as an absolute form with fixed concepts about author and style. This would be a valid observation. Husain also sees the Western perception about modernism not applicable insofar as the Indian art is concerned.

A good historian interpreter Eisenman (1994) has presented an interesting view about modernism. The efforts of the modern artists throughout the $19^{\text {th }}$ - century to assert their connection to the Classical past was guided by the idea of linking its connection with the present. Poetry plays a role in such connection. Eisenman puts his argument by citing these words of the French modernist poet Baudelaire, "The true painter we're looking for will be the one who can snatch from the life of today its epic quality, and make us feel how great and poetic we are in our cravats and our patent-leather boots." That is a symbolic and poetic reality of the presentism. Eisenman stresses on the Classic connection of modernism in these words, "modernism as it evolved in Europe and North America over the course of $19^{\text {th }}$ - century, was not so much a rejection of older $19^{\text {th }}$-century, was not so much a rejection." (304). He gives example of Van Gogh's distortion of 'normal harmonic scale progression through the introduction of colour accidentals' almost to point of abstraction. And that had this connection with the normal, the classical because the intention of such distortion was not 'to destroy the art of portraiture but to save it' to make it 'vehicle for the revelation of human 
character....'. But symbolism, he says, was rejection of the European mimetic tradition. Very significantly he links such rejection as the pioneering of a new art of sensual liberation and personal expression founded in part on nonWestern "primitivism". And to show how the conflict arose, he mentions as example the irregular terrain of Cubism, the abyss of nonrepresentation, and the revolutionary dreamscape of "Surrealism". (305).

The essence of discussions about modernism in our part of the world by critics and also by artists like Husain therefore, cannot be understood by following the linear history of Western modernism that was experimenting and going through a process of crisis in the nineteenth century. The modernist experiments that happened towards the end of the $19^{\text {th }}$-century and the early $20^{\text {th }}$-century Europe was dealing with the most creative, challenging and experimental 'crisis'. The discussions that were happening during that period in Calcutta thus hold great significance. That is the reason why I value the exposure of the above mentioned two Nepali painters Maskey and Chitrakar as a very important historical event in our discussions about modern paintings in Nepal. This subject should be treated in separate article. As I have covered some of that in my previous article, the first part (Subedi, "Nepali paintings and poetry: reviews and reflections"), I am careful here not to repeat the same discussions.

Modernism, therefore, is the name of the very significant evolution of a consciousness that is expressed through changing artistic forms. But the nature of such consciousness can be seen most productively in the interface of arts and literature and their expanding spheres. That is why perhaps, any serious discussions about modernism in art in the West cite the words of the modernist French poet of the city, a flaneur Charles Baudelaire. Artists have worked by sharing a spirit, and by living with the same modes of consciousness as the writers, poets and the art pedagogues. We do not understand modernism by ignoring this art-literature interface. The examination of the history of changes and experimentations in art in the Indic region and its impact on Nepali art, therefore, holds great significance.

\section{Changing perceptions of Nepali writers and painters}

Writers have been eloquent about the changing perception of paintings and sculpture in this region and the West. Observations of the doyen of modern Nepali drama Balakrishna Sama (1902-81) would open up further grounds of that interface between art and literature. Though I have already written about that in the first article on this subject, for the context of the argument I want to cite here a section of that in which I have described what I would like to call my understanding of the first critical perception of the consonance of modernist art and poetry by the Nepali dramatist, theatre person, painter and poet Sama in the text of a brochure text that he wrote for the painting exhibition of the now eminent painter Laxman Shrestha held, I guess, for the first time at NAFA Art Gallery in Naxal in the year 1967. I had seen at the suggestion of the dramatist. The consonance between paintings and literature $-\mathrm{a}$ true recognition of the interface of the two, becomes manifest in the lines I 
have cited. In the brochure Sama has mentioned about the very essential element of cross-art resonance, which I think is the first recognition of the power of painting as a mode of cultural expression in Nepal. We should seek the early ideas about modernism of Nepali art in observations, trainings, forms and exhibitions.

In that brochure Sama asks, and I translate, "Why do painters and sculptors shift first from abstract to fine and to abstract from the fine forms?" To answer that question Sama very meaningfully takes recourse to the tradition of experiments in the Western paintings. Though Lain Bangdel's what is believed to be the first modern paintings were exhibited five years earlier, no critical reviews with modernist perceptions were available until then, and we had to wait for quite some time for that. Sama's description of Laxman's paintings shows the first meta-poetic or meta-artistic perception made by anybody in Nepal until then. He takes recourse to answer that to the Indic tradition of art and literature as MF Husain does as cited earlier. I quote some lines from the first part of this article published in this magazine:

He mentions the abstract and symbolic characters of Hindu icons like the rudrākshya and Saligram stone - the former is a prayer bead, hard body of a fruit, and the latter a fossilized shell or stone--and says, the concept of abstraction is not alien to us. He claims, by the same token, the Nepali connoisseurs find it easier to understand Picasso. I find this claim little romantic on the part of Sama, because there were very few art viewers at that time and fewer still from those who had even seen any pictures of Picasso's paintings. But Sama makes his point here. He wanted to say that Laxman Shrestha's paintings were abstract and he had seen his future in that form. He says, "my conviction is Laxman Shrestha by painting abstract pictures of the mind on the grey walls with his brilliant imagination and great talent, has enhanced the prestige of the Nepali art world." Sama's sense of the similarity of literary and artistic form finds a tremendous expression in the analogy that he sees between the great Sanskrit poet Kalidasa's poem Rativilap and Jackson Pollock's paintings. There is similarity in their way of presenting the picture of the mind. I feel amazed today by recalling the talent and the range of understanding of art of this dramatist of the erstwhile era in Nepal. (Subedi, "Nepali poems and painting", pp. 9-10).

There have been scanty meta-artistic discourses in Nepal not least about modernism in paintings. The literary critics and creative writers are more eloquent about modernism in literature than the artists and art critics are about arts. However, modernism as a concept has made inroads into cultural discourses in Nepal influencing both art and literature, which should be carefully analysed. However, we should understand that the artists, or the painters themselves would not talk volubly about their art works. Some artists love to do that, but the veracity of those chatters is a subject of scrutiny. Some who are also writers have tended to do that more than the others. But my 
conviction is that research in paintings or art is a subject of greater interest for the critics, than for the artists. That is true everywhere. Research, Pablo Picasso said is not the priority of painters. Picasso says, "I can hardly understand the importance given to the word research in connection with modern painting. In my opinion to research means nothing in painting. To find, is the thing" ('Picasso Speaks', 210). He adds, "The idea of research has often made painting go astray, and made the artist lose himself in mental lucubrations. Perhaps this has been the principal fault of modern art". (211).

Nepali discourses about modernism do not appear to show preoccupation with research. The artists as well as the commentators dwell more on style than on the actual treatment of the motifs. Ostensibly, these features are naturally propelled by the shift in the treatment of figurality; they turned them into abstract forms. However, that does not necessarily capture the quiet albeit experimental treatment of the subject by highlighting the significance of research for that.

My view is that the underlying spirit of the painter is inspired by the excitement of change in themes not especially in the innovative thoughts. That is a very important subject of Nepali art that lies dormant. But as a writer and literary critic, I have found that modern Nepali artists - largely painters, and sculptors on a lesser scale-appear to be working with the same spirit, the same moments of findings, and the same exciting modes of experimentations as the literary writers. This is so true in the case of the Western artists and poets. A considerable number of studies have been published over the years, some notable like the Surrealists and symbolists movements and others as academic subjects. That tradition has had a significant influence in South Asia, especially in the Indic region. We should see the nuances of the transitional times to understand modernism. It is important to see how much of the concept of modernism has Western origin. Among the many discussions about this subject, art teachers and commentators often draw one conclusion alike-modernism in the West draws motifs from Asia and Africa. Books and articles are available on this subject.

The common grounds that modernism in art and literature in Nepal share have triggered limited responses among the art interpreters and literary critics in Nepal. The interface of the two has not found forums of discussion even though the two genres of art share the same spirit, the same anxieties and the same tantalising moments of experimentalism. This has happened all the time, and more in the contemporary times. As I have already written about the relationship of poetry with paintings in the first part of the article, I would like to discuss about the meta-literary discourse involving modernism here.

The meta-literary discourses occurred in the long sixties of the last century. I have written about the literary modernism and the modes of meta-literary discourses over many decades. So to avoid this article being a literary discourse and also due to a lack of space, I would like to give one reference out of several I have written about modernist writings in Nepali. In the preface to a collection of 'representative Nepali modern poems' or pratinidhi nepali adhunik kavita I have 
discussed the features of modernist literary culture in general and Nepali poetry in particular. (Subedi, "Nepali kavitama adhunik prayog", 2067 BS). Similarly, I want to give reference to my other article that directly addresses the subject of relations between Nepali poetry and paintings (Subedi, "Modern Nepalese poems and painting", 1992).

But for the purpose of discussing the meeting points of modernist art and poetry or literature, I would mainly focus in the following paragraphs about a literary movement that directly emulated the styles of modernist art in their writings, or, they claimed they did. I have introduced this movement in my book written earlier:

A slim literary magazine named Tesro Ayam appeared from Darjeeling in May 1963, which contained a few poems, a few stories and an editorial article. The editorial article was, in essence, the manifesto of a group of poets and writers who claimed that they were going to write in an entirely new vein. They claimed that they were breaking with the prevalent norm of writing. Three people, Indra Rai, Iswar Ballav and Bairagi Kanhila launched the movement. The latter two are poets and the first one is a short story writer, a novelist, a literary critic and a thinker. The editorial article defined the Tesro Ayam literature (or the third dimensional writing) in this manner:

The writing of today must present a total picture of man. A man is the sum total of all his senses, heart and mind. Literature should depict this totality of man. To do this, literature should break away from the norm of one-dimensional literature. The depiction of life should be elevated from the individual to the universal level. Such literature should be a curious blend of philosophy, politics and intellectuality. Then, that will be a third dimensional writing. (My free translation). (Subedi, Nepali Literature: Background, 80 ).

Among the three members of this movement Indra Rai produced important meta-literary discourses. His entire oeuvre includes fiction, literary criticism and theories. Rai as a literary writer foregrounds the subject of modernism with paintings and literature sharing the same culture, and even forms. After Sama's short observation mentioned earlier, Rai's meta-discourses remain ignored in art criticism. In the following paragraphs I have presented the gist of his meta-literary and artistic arguments. He is highly influenced by the Western paintings and modernist thoughts, but is fully aware of the Indic and indigenous traditions. But as the following arguments show, he liberally uses the Western discourses about arts and literature. But, as I confessed earlier, much of what is written about modern Nepali paintings and literature, the overt use of the Western canons to a considerable extent is unmistakable.

Writers have written little about their karma of sharing experience with artists. But the most conspicuous landmarks in such efforts have appeared in the forms of creative literary writings. That is why Indra Rai's meta-literary essays explaining how their kind of literary writing shares characters and values with modern paintings is so important to understand the nature of the interface 
between the two forms of art. By the same token, these meta-discourses are very important insofar as modernist consciousness in Nepali writing is concerned. But we should note here Indra Rai has used the paintings of the pioneer of modernism in Nepali art, Lain Bangdel in his discussions.

In an article entitled chitra or painting included in his book (Rai, 1972 ) Indrabahadur Rai meticulously explains the interface of modernist literary writing that they named tesro aayaam as mentioned above. This essay is very cerebral in its structure and semantics. Rai heavily draws in this essay references from his theoretical reading of the Western schools of thought in arts and literature, which he writes in a very complex aayaamik style. Most Nepali literary critics without delving into the subject accept it as a 'third dimensional' literary discourse. I think it would be very important to discuss some of Rai's interpretations of the interface between paintings and literature albeit he has drawn most of his examples from Western critical and art theories.

He begins by saying, "We used the language that was similar to that of paintings". He reveals that they were treating language and creating a texture of writing as the abstract paintings do. Literary language is freely experiented in such use. It is not only painting, music also shares the features of composition with literature (94-95). Explaining their method Rai says, not content with the surfacial similarities we seek a deeper consonance with arts - not only between art and their writing but also with music. Such consonance lifts literature to the lelvel of art. Elaborating this further Rai adds, the very purity of literature is its artistic quality. Art, music, literature, science, philosophy, research and progress move together. Rai's concept of modernity is very broad-based. I find this logic a little too diffused especially when it drifts from the above argument he has made about the relation between art and literature.

Rai stresses on the importance of the consonance that exists between painting and poetry. The reason why he puts science here is that a literary writer and a painter should act with the confidence that art and literature need not be threatened by science. Instead, they should remember, "When the scientists were analysing light, the artists were studying light on the canvas. Painters Constable, Turner, Delacroix were working with light and shadow, reflections and milieu in the paintings. The architect of the Surrealist movement launched in 1920 was poet-artist Andre Breton. Rai sees T. S. Eliot's poem "The Waste Land" and the 'protean' vision of Rambaud doing the art works in words. (98-99). Rai creates a list of 10 major Western paintings to show how their aayaamik literary writings use similar methods of creating works of art.

Rai, a fiction writer and interpreter and the modernist poets of his group worked with the confidence that their works were similar to those of the painters. That is the reason why I see the need to stress on the study of the interface between art and literature in modernist Nepali literature as well as paintings whose sphere is expanding.

Rai's interpretation of paintings and literature moves in a style that he would call third dimensional, which means writing or interpreting art and literature 
is done in a language that is closer to the composition of paintings on canvas. This raises a heuristic question - can you use the language of the criticism too in the style of a painting? The reason for that inquisition would be that ideas in a painting stand out through the devices that are meta-artistic in nature. The use of colours-primary, secondary, tertiary or free mixing - brush strokes and their flow or movements, their mood understood through expressionist devices, figurality that includes both anthropomorphic, and metaphorical or symbolist in character are the devices of projecting thoughts and moods in paintings. We can also ask - can you do the same with language in fiction or poetry? The answer may require discussions. I find that as the enthusiastic use of artistic forms in writer-created problems of communication. Rai justifies such use in poetry and creative prose. He says, poet Baudelaire's quest was one of transcendental beauty and fulfilment characterised by hatred and disillusionment. He rejected fine forms in favour of the abstract ones. He regards the symbolist French poets Rimbaud and Mallarme sharing similar views. (104).

Rai further explains the abstract forms or non-figurality in his other essay "Mulya" or 'value'. Non-figurality is an intense reality not a window from where to look out at the world outside. He calls this vastutaa or objectivity, and by the same token, the way of experiencing the world. In painting that would be called sensa. He appears to be close to evoking the Kantian philosophy in some important respects, but we can also see him arguing like an 'piricist. He stresses on experience as an important element that constitutes his concept of meaning. (107). In reality,
Rai attributes more philosophical perspectives to explain writing as the emulation of the objectivity vastutaa. As a literary writer, and very significantly, he sees short fiction, poetry and plays and the universal features used in ancient tales. (110).

One very crucial point of meta-artistic discourse evoked by the tesro aayaam argument is that literature should depict life in its 'totality' from all angels and sides like a sculpture, but Rai says as in the above argument, it should depict life like an abstract painting. The concept of vastutaa is one of a total and three dimensional perception of reality. That is absolutely fine. But to stress on the abstract painting achieving that is problematic. I often argued with Indra Dai about this subject. But his concept about the abstract art was that such art achieves totality by dismantling the classical or what he called the flat two-dimensional forms. But interestingly, the reality is just the opposite. It would be very relevant to cite the views of the famous art critic and scholar Greenberg here. He says, "The limitations that constitute the medium of painting - the flat surface, the shape of the support, the properties of pigment considered negative factors by Old Masters, were considered positive by modernists. (Greenberg 755). He adds, "Modernist painting oriented itself to flatness as it did to nothing else." (756). He claims, "Some of the greatest feats of Western painting came as part of the effort it has made in the last four centuries to suppress and dispel the sculptural." That means the paintings did not represent the sculptural quality. But the writers of the third dimensional school believed that the abstract art does 
represent the totality, which means a total meaning or a holographic picture of life, and they saw that in modern art.

But Greenberg says, "The Cubist counter-revolution eventuated in a kind of painting flatter than anything Western art had seen since before Cimabueso flat indeed that it could hardly contain recognizable images.' (757. My emphasis).

To avoid repetition of what I have already discussed in the previous article, I would like to mention some features of modern art in Nepal. I consider Lain Bangdel as the pioneering modernist painter of Nepal. Bangdel's first exhibition of his paintings was made at Saraswoti Sadan of Tri-Chandra College in 1962 that was inaugurated by king Mahendra. Though B. P. Koirala had convinced Bangdel to come to Nepal from London where he lived, in 1956, it is known now that king Mahendra had practically invited him to come here and head a department of art at the then Royal Nepal Academy. Bangdel was both a modern painter and writer.

Bangdel's example is very eloquent in this discussion about the interface of modern art and literature. We should mention the history of Bangdel's art education in Paris where he met writers like Albert Camus, Andre Malraux, Jean Cocteau, and painters Picasso and Braque. He was influenced and thrilled by the meetings with these writers and painters. He productively combined the education and meetings with the writers and painters. That genesis of the interface of paintings and literature should be remembered. (Subedi, "L' éducation des artistes." 76). In a very remarkable book about Bangdel that Don
Messerschmidt wrote with Dina Bangdel (2004) we can see how a painter Bangdel and writer Bangdel grew and flourished together. During that period, Bangdel also met Indian artists like Raza, Souza, Padamsee, Krishna Gairaula and others at Ecole des Beaux Arts.

Messerschmidt (2004) presents Bangdel as a literary writer and painter; he puts that under the title "Bangdel's Art". Don includes three of his novels Muluk Bahira or 'Outside the country' (1948), Maitighar or 'maternal home' (1950), Langadako Sathi or 'The cripple's friend' (1951). Don has cited from my earlier article on the subject of human animal friendship in Bangdel's novel. (Messerschmidt 126). I have said, there is a great consonance between Bangdel's novels and his paintings. This essence, this interart relationship between his modern paintings and literature is one good example of the interface between paintings and literature.

\section{Nepali modernists: personal encounters and reviews}

In this section I would like to recount some of my personal experiences with the modern artists that include being a fugitive model for them, a participant in discussions and a performer before them. These encounters, I believe, capture the moments of the artists' works and their impression on me as a literary writer and an academic commentator. All of these encounters happened with the painters of at least two generations whom I for heuristic reason would call modernist.

I have seen from close proximity how the modernist painters work and what they share with literary writers and theatre people like me. The senior painter Uttam Nepali, Laxman Shrestha who is based in 
Mumbai, SKIB artists, Kiran Manandar, Vijaya Thapa, Sashikala Tiwari, Ragini Upadhyay Grela are all modern artists who have shared their experiences with the literary writers, especially poets. I have only mentioned those artists who I have personally shared experiences with, encountered their interart moments and performed with them on theatre variously. As I have already written about such encounters with painters of different generations, I do not want to repeat that here.

As I have written elsewhere Uttam Nepali who was a modern poet made his first major interart experiment by exhibiting 32 paintings with modern lines of poems by various modern poets of that time written, rather inscribed on the canvases at NAFA Art Gallery in September 1975. I have written the following words about this exhibition:

His style of representing poetry in art was by directly writing short text along the conceptual dimension of the painting. The title of the exhibition was 'Poet, Poetry and Painting', a straightforward title. He sought to combine these three forms in each painting through the medium of abstract art. ... The line/ lines form part of the sensa in the abstract painting. Sensa in abstract painting is what the voyeur sees on the canvas, the colours, abstract forms and movements of lines that do not form any figurality." (Subedi, 'SKIB in textual and visual memories', 8).

The modernist painters represented by the acronym SKIB are Sashi Shah, Krishna Manandhar, Indra Pradhan (the late) and Batsagopal Vaidya. I worked closely with them as literary writer. "SKIB however continued to foster that spirit, that sense of the confluence of art and literature. But they continued to be painters or artists par excellence." ("SKIB in textual", 8).

I have several memories of close encounters with the modern painters. I sat on a hillock in Ngarkot on Octorber 12, 2007 at an interart confluence organised by Gurukul theatre facing the modern painter Vijaya Thapa who was, as he said, reading my face and expression as well as sharing our experience about arts. (For Peace and New Nepal). He was executing my portrait. That portrait is fluid and modern in style. That portrait hanging on my wall reminds me about a covenant between a painter and literary writer. Another modern well-known painter Kiran Manandhar worked with us on theatre. He jumped on the stage with a huge canvas when we were preparing for staging a modern performative poem entitled "Kathmandu Odyssey" that I had written to capture the mood of the times and history in 1996. (Subedi, Kathmandu Odyssey). This book is extensively illustrated with drawings by Kiran Manandhar. His understanding of the poem, and the theatre, as well as his interpretation of those complex moments in lines is remarkable. He has worked with theatre artists, musicians and poets in different places on a number of occasions. As this article is exclusively addressed to the subject of the interface between modern paintings and literature, I have only cited a few related events, and have put my own experience and my direct encounters of the moments of creative crises that have 
mostly gone unnoticed. As these are important moments in the study of the creative culture of Nepal with paintings and literature sharing motifs and moods, I have chosen to write only this much for this second part of the writing about artists and literary writers especially poets. I have excluded sculpture for reason of space.

I would like to close by writing about an anarchist modern painter who is also a literary writer. His name is Manuj Babu Mishra who is known for the meta-artistic interpretations. His oeuvre mainly contains his caricature. Sangeeta Thapa, a very well-known art curator and art critic says this about him, "Manuj Babu's forms of meditation to be highly self-indulgent or narcissistic, a study of Manuj Babu's drawings reveals the work of an artist who has no qualms about caricaturing himself". (In the Eye, V). His confession shows him both as a modern painter and a literary writer. He says, "I constantly dip into the depths and shadows of my time. My drawings are meditative. ... My art works have emerged from the site of rubbish dumps, from the dust and mud." (In the Eye I).

Mishra has written about art and spoken to journalists. In one such chatter Mishra has compared his paintings with faeces - not uncommon for him to use scatological imagery-because the relief that he experiences after completing a painting is similar to the relief that he would experiences after evacuation. He does not believe in god. If he must he would take his paintings and the late autocratic king Mahendra as his god. (Mishra, 'Nepalma Samikshyak...'). Mishra enjoys the tactile sensation when he draws close to his art. His painting with the artist kissing the cheek of
Mona Lisa is the figural expression of Mishra's meta-artistic consciousness. He uses proximity and touch as the favourite modes of his art. The bizarre and surrealistic figurality, some even showing war missiles passing through the artist's head constitute a mode of expression that no other modernist painters have used in Nepal. I want to cite from my article about him published in Sirjanā:

I have one very revealing moment to share. One day, in one of my visits to his house, he wanted to draw my portrait. I sat in front of him talking. After working for sometime, he rejected that and started to do another portrait. I asked him why he had cancelled the first. I felt deep down the power of his art when he said, "the face of a person, and that also of a writer, is a flow, a movement. It is not just the face, but the outer world also that the artist should be able to capture in that portrait". The 'world' reflected in my portrait that he has "included" in the book Drawings of Manuj Babu Mishra, is a poet that I have not yet been able to decode fully. (Subedi, "My understanding", 15).

That tacit understanding, that incomplete art and that creative confrontation between the modernist painter and a literary flaneur, and a number of similar encounters between the practitioners of the two genres of art is the essence of the interface between painter and writer in Nepal.

\section{Conclusion}

We have customarily been writing about modernism in Nepali paintings as any other interpretation would be written 
on the subject. Modernism in that sense is interpreted on the basis of the Western canon. I have written scores of articles and catalogues by following the canons about modernism. I have written extensively about modernist Nepali poetry. Over the years my perception about modernism in Nepali paintings has changed especially after following the theme of apprenticeship, training or education acquired by painters and sculptors of this country at different times and in different institutions outside Nepal because there were no such well-provided facilities and teachers here. Art critics like Narayanbahadur Singh (1976) and others have used different theories about looking at modernism in Nepali paintings. They have used different styles and techniques of artists to discuss about the tenets of the modernist movement. They have used the individual artist's modes of paintings to prove their argument. I want to add a note of confession here. In my entire bulk of art criticism that I have written do I realise today, I followed the same linear interpretations. Though in my discussions about modernism in literature I have used the historical and educational features leading to the modes of shifts in the genre, I have not done the same to look at the modernism in art by using similar perspective. The artists themselves are not supposed to be theorising about their arts, but they have brilliantly been showing their flexibility in their choice of techniques and influences. In this article, therefore, I have tried to locate and explain the landmarks that importantly include the exposures of the artists to new modes and techniques. And that started mostly with their formal and some informal trainings in the modern techniques of art, a phenomenon that I have discussed albeit briefly in this article.

The greatest single factor of modernism in Nepali art is education that opened new era in this area. Modernism, I strongly believe, began with the art education of Chandraman Singh Maskey and Tejbhadur Chitrakar at the turn of the $20^{\text {th }}$-century. Their education means their exposures, dedication and thereafter their lifetime dedication to the spread of their art through hard work and pedagogy. I would also add the names of Keshav Duwadi and Kalidas Shrestha and a few other contemporaries who came after them. But this article not being a history, I have selected the above artists who were witness to the genesis of modern art that was beginning with the dialectics between Orientalism and free art in this region. As an avid reader of the art movements in Bengal, especially Calcutta alias Kolkata by following a postcolonial reading of the subject, I was drawn by the power of the dialectics between the traditional Orientalist gurus and the free wheeling painters of Bengal. That creative tension lay at the heart of the matter. That was directly related to education in art. Though we have a long tradition of traditional art in this country, Nepali artists' exposure to Western art, techniques, mediums and the effulgence that the artists experienced is the most important element of modern Nepali art. Such skills were also acquired by some artists who did not attend the modern art schools; this is another side of study for the art critics. The outstanding example of Purna Man Chitrakar is one of them. Madan Chitrakar rightly calls him 'least celebrated' artist. ("Purna Man"). Why he was least celebrated opens a new avenue of studies of artists of the traditional 


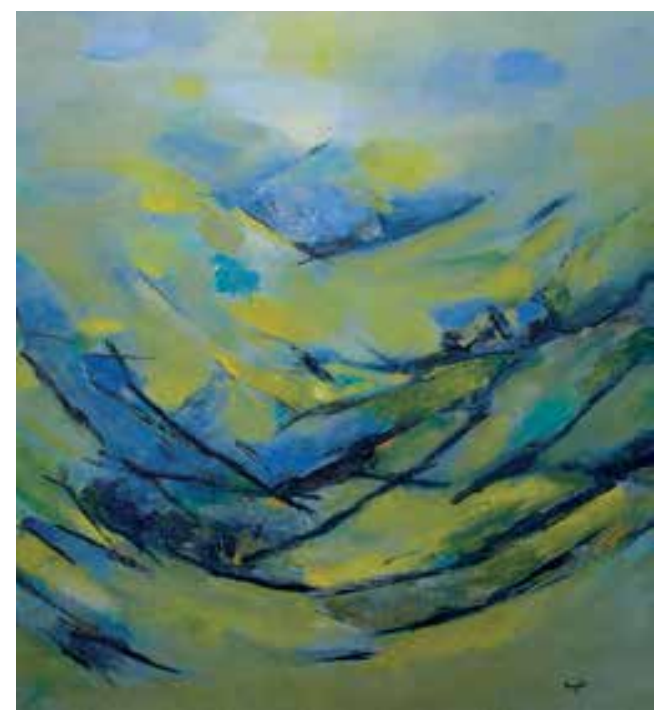

Lain Singh Bangdel, A painting from the mountain series, circa 1970s, Oil color on canvas.

background nonetheless acquiring the skills of Western portrait art, figurality and landscapes that we find in the works of the other self-educated artists.

It may sound like a little breach of critical canon when I repeat the above argument and say the two young artists Chandraman Singh Maskey and Tej Bahadur Chitrakar who were sent to study art in Calcutta the hub of the creative dialectics in the year 1918, were the pioneers of modernism in Nepali art. What they learned and what the artists did in Bengal was by no means modernist in the sense of the term, as we know today. But that era and those experiments and debates of that time were the pioneering features that introduced the creative tension in art that opened up new avenues in art that included modernism. I have discussed that subject in this article.

The following era that began with painter Lain Bangdel, who was also a literary writer, with his exhibition of paintings executed in Western modernist style in 1962 introduced abstract paintings. I would take this exhibition as the second milestone insofar as the opening of the second phase of modern Nepali paintings is concerned. The last quarter of the $20^{\text {th }}$-century saw the artists trained in good art schools or colleges thus getting exposures to the different realms of art. I would call the entire development as the widening of sphere without solely focussing on the styles and motifs of paintings. But the main question is how do we understand these transformations? My theory is that the creative cultural dynamics was responsible for the widening of the sphere. Such widening of sphere with arts and literature sharing experiences is a theme that dominates most crucial discourses on the subject in the West and other parts of the world, in what Geeta Kapoor as cited above says, "Modernist myths tested once they cross the threshold and encounter cultural modalities of modern as it is actually practised around the world." For that, both as a literary writer and art commentator, I have concluded that a direct and tacit understanding between the painters and the literary writers is essential to understand those encounters, and the very significant widening of spheres of the creative arts and literature in Nepal.

\section{References}

Barker, David K.(nd). Retrieved from: https:/ / issuu.com/dkbbkk/docs/maskey-3

Berger, John. (1972, 2008). Ways of Seeing. Penguin.

Chalmers, Rhoderick (2004). We Nepalis' Language and the Formation of Nepali Public Sphere in India. (1914-1940). PhD thesis. School of Oriental and African Studies. 
Chitrakar, Madan. (2004 a.). Tej Bahadur Chitrakar: Icon of a Transition. Kathmandu: TeBaChi Studies Center.

Chitrakar, Madan. (2018 b.). Purna Man Chitrakar (1864-1939 AD): A Pioneer - Least Celebrated, Sirjanā. 5, 16-27.

Eissenman, Stephen F. (1994). Nineteenth-Century Art: A Critical History. London: Thames and Hudson.

For Peace and New Nepal. (October 11-14, 2007). Creating Camp for Peace and New Nepal at Nagarkot. Kathmandu: Gurukul.

Greenberg, Clement. (1992). Modernist Painting. In Charles Harrison \& Paul Wood (Eds.). Art in Theory (pp. 754-760). Oxford: Blackwell.

Husain, MF. (2012). An Artist and a Movement. Beyond Borders, 7 (1), 57-58.

In the Eye of the Storm: Drawings of Manuj Babu Mishra. (2009). Kathmandu: Nepal Investment Bank.

Kapur, Geeta. (2012). Modernist Myths and the Exile of Maqbool Fida Husain.

Beyond Borders, 7(1), 15-27.

Mishra, Manuj Babu. (2016, June 25). Nepalma samiksyak nai chainan. Nagarik.

Messerschmidt, Don with Dina Bangdel (2004). Against the Current: The Life of Lain Singh Bangdel: Writer, Painter and Art Historian of Nepal. Bangkok: Orchid Press.

Picasso, Pablo. (1992). Picasso Speaks. In Charles Harrison and Paul Wood (Eds.) Art in Theory 1900- 1990: An Anthology of Changing Ideas. (pp. 211- 213). Malden and Oxford: Blackwell.

Rai, Indrabahadur. (1972). Kathastha. Darjeeling: Nepali Sahitya Parishad.

Singh, Narayanbahadur. (1976). Samasamayik Nepali chitrakalako itihas (History of Contemporary Nepali Arts). Kathmandu: Royal Nepal Academy.

Subedi, Abhi. (2016 a.).Twilight zones of Nepali sculpture. Sirjanā, 3, 24-35.

Subedi, Abhi. (2017 b.). Nepali paintings and poetry: reviews and reflections. Sirjanā. 4, 7-20.

Subedi, Abhi. (2019 c.). SKIB-71 in visual and textual memories. Sirjanā, 6, 7-19.
Subedi, Abhi. (2018 d.). My understanding of Manuj Babu and his art. Sirjanā, 5, 7-15.

Subedi, Abhi. (2020, November 8 e.). Ambivalence in modern Nepali arts. The Kathmandu Post.

Subedi, Abhi. (1978 f.). Nepali literature: background and history. Kathmandu: Sajha Publication.

Subedi, Abhi. (1992 g.). Nepalese poems and paintings: canons and contexts. Contributions to Nepalese Studies. 19, 1-17.

Subedi, Abhi. (2017 h.). L'éducation des artistes népalais en Inde et en France: leur impact sur l'art moderne népalais. Rencontre avec l'Inde. (pp. 72-82). Delhi: Conseil Indien pour les relations culturelles.

Subedi, Abhi. (2067 BS i.). Nepali kavitama aadhunki prayog, or modernist experiments in Nepali poetry. In Taranath Sharma et al (Eds). Pratinidhi Nepali Adhunik Kavita. (pp. 1-48). Kathmandu: Nepal Pragya-Pratisthan.

Subedi, Abhi. (1996 i.) Chasing Dreams. Kathmandu: Mandala Book Point.

Woolf, Virginia. (1910). Mr Bennett and Mrs Brown. Retrieved from: https://www.bl.uk/ collection-it's/mr-bennett-and-mrs-brownby-virginia-woolf. 